\title{
HUBUNGAN LAYOUT PERUMAHAN DAN FAKTOR KRIMINALITAS DI PERUMNAS AIR PUTIH SAMARINDA
}

\author{
HIDAYATI, Zakiah \\ Program Studi Arsitektur, Politeknik Negeri Samarinda \\ Jl. Cipto Mangunkusumo, Samarinda \\ Email: zakitec@yahoo.co.id
}

\begin{abstract}
ABSTRAK
Pertumbuhan kota Samarinda yang pesat menyebabkan timbulnya berbagai masalah lingkungan yang harus dihadapi oleh masyarakat. Tekanan lingkungan dapat berupa tekanan fisik, sosial dan ekonomi. Salah satu bentuk tekanan sosial adalah kriminalitas. Angka kriminalitas cenderung naik di daerah perkotaan, seperti pada perumahan rakyat. Layout perumahan dan kriminalitas menjadi dua parameter dalam penelitian ini. Tujuan penelitian adalah menganalisis hubungan antara layout perumahan dan faktor kriminalitas di Perumnas Air Putih Samarinda. Metode penelitian yang digunakan adalah kualitatif-deduktif. Penelitian ini adalah penelitian empiris yang menggunakan studi kasus. Hasil penelitian : faktor yang paling berhubungan antara layout perumahan dan kriminalitas adalah koneksi langsung antara rumah dengan akses perumahan (koneksi langsung meningkatkan kriminalitas), kedalaman ruang (semakin dalam posisi rumah maka akan semakin aman), indeks axial connectivity (semakin tinggi nilai indeks maka semakin rawan kriminalitas) dan mixed use (semakin banyak rumah di dekat area fasilitas akan menciptakan area yang lebih aman dibandingkan dengan sedikit rumah di dekat area fasilitas). Faktor yang sedikit berhubungan adalah bentuk akses (langsung/tidak langsung) ke hunian, kepadatan lalu lintas, lebar jalan dan posisi rumah pada deret linear. Faktor yang tidak berhubungan adalah bentuk akses (langsung/tidak langsung) ke Perumnas dan zona 1-4, kedekatan rumah dengan persimpangan jalan, bentuk deret rumah, dan arah fasad rumah.
\end{abstract}

Kata kunci: Layout perumahan, kriminalitas.

\begin{abstract}
The enormous growth of Samarinda confronted the people with great problems of environmental pressures, included physical, social and economic factors. One of the social factors is crime. Crime rates tended to increase in urban areas, such as in public housings. Layout of public housing and crime were the two parameters. The object of this research was to analyze the correlation between housing layout and crime in Air Putih Public Housing, Samarinda. The method was deductive qualitative research. It was an empiric research, using case study. The results of this research, most factors correlated between housing layout and crime, were direct connection between single house with housing access (direct connection increased crime), the depths of space (the deeper space created more secure), index axial connectivity (more scores of index - more crime vulnerability), and mixed use (more houses near facilities area created more secure - while less houses created more crime). Less factor were access (direct or indirect) to a single house, traffic jam, width of the road, and house position in row. Unrelated factors were access (direct or indirect) to Perumnas Air Putih \& zone 1-4, adjacency of single house to road junction, linear row, and house facing direction.
\end{abstract}

Keywords: Housing layout, crime.

\section{PENDAHULUAN}

Tindak kriminalitas cenderung meningkat di berbagai kota-kota di Indonesia. Ragam kejahatan pun semakin bervariasi. Pencurian, kejahatan di dunia maya, penculikan, perdagangan manusia, korupsi, illegal logging, kekerasan dalam rumah tangga, vandalisme, pencucian uang dan peredaran narkoba adalah sebagian contoh tindak kejahatan yang mengepung kehidupan masyarakat di semua lapisan. Pelaku kriminalitas pun mewakili berbagai kalangan, laki-laki, perempuan, anak-anak, remaja, orang tua, berpendidikan, tak berpendidikan, kaya, dan miskin. Kriminalitas terjadi di semua ruang masyarakat seperti di area perdagangan, sentra industri, area pendidikan, area pariwisata, perumahan dan lain-lain.

Perumahan dan kriminalitas menjadi hal yang penting untuk diteliti karena perumahan sebagai tempat tinggal bagi masyarakat, menyimpan potensi menjadi ruang yang tidak aman (dari kriminalitas), dan hal ini menjadi isu terutama di kota-kota besar, baik itu di Indonesia ataupun di luar negeri. Oscar 
Newman termasuk arsitek yang banyak melakukan penelitian bertema perumahan dan kriminalitas. Salah satunya adalah penelitian dalam proyek The Security Design of Urban Residential Area (rancangan aman pada kawasan hunian kota). Didapat kesimpulan bahwa bentuk rancangan tapak suatu lingkungan perumahan bisa mempengaruhi tingkat kerawanan kriminalitas bagi penghuni lingkungan perumahan tersebut. Suatu lingkungan perumahan bisa dikurangi atau dihilangkan kerawanan kriminalnya dengan membuat rancangan fisik sedemikian rupa sehingga lingkungan tersebut bisa membentuk suatu defensible space (ruang yang mampu bertahan). Hasil penelitian ini kemudian dituliskankan Newman dalam buku berjudul The Defensible Space (1972).

Makna 'space' dalam Defensible Space sendiri memiliki interpretasi bermacam-macam. Hal ini dapat membingungkan dalam proses analisis yaitu penentuan unit analisisnya, tetapi Newman mengklaim bahwa konsep Defensible Space dapat diterapkan dalam lingkungan masyarakat dari berbagai level, dari apartemen hingga ke jalan, tetapi perbedaan spasial ini tidak diungkapkan dengan jelas di dalam bukunya.

Perumnas Air Putih dipilih menjadi obyek penelitian karena merupakan perumahan tertua di Samarinda yang dibangun pada awal tahun 1980. Jika umumnya Perumnas terletak di pinggir kota, maka Perumnas Air Putih berada di tengah kota, terdiri dari hampir 1000 rumah dengan tingkat hunian hampir 100\%. Entrance Perumnas Air Puth dapat diakses oleh semua masyarakat Samarinda dan dapat dilalui berbagai moda kendaraan pribadi (sepeda motor dan mobil) dan kendaraan umum (angkot, truk dan lainlain). Lebih dari 30 tahun tidak ada perubahan layout perumahan. Kejadian kriminalitas terus meningkat di Perumnas Air Putih, terutama pencurian dengan pemberatan. Karakteristik Perumnas di atas menjadikan Perumnas Air Putih menjadi lokus yang tepat bagi penelitian ini, untuk selanjutnya dapat dimanfaatkan sebagai bahan pertimbangan dalam perencanaan perumnas terutama di kota Samarinda.

Hunian di Perumnas Air Putih memiliki kondisi layout yang berbeda-beda di titik-titik tertentu. Layout yang berbeda-beda diduga menghasilkan level kerawanan kriminalitas yang berbeda-beda pula. Layout perumahan meliputi akses, pola hunian, pola sirkulasi dan fasilitas (Untermann dan Small, 1983). Kemudahan akses adalah hal penting yang perlu dipertimbangkan dalam perencanaan perumahan. Beberapa jenis akses ke unit perumahan dalam Untermann dan Small (1983) adalah direct street access, courtyard related, dan akses dari tempat parkir bersama. Bentuk pola hunian dalam perumahan (Untermann dan Small, 1983) adalah pola hunian memanjang (linear satu sisi), sejajar (linear dua sisi), pola hunian cul de sac, mengantong, dan melingkar. Sedangkan pola sirkulasi menurut Joseph de Chiara dan Lee K. (1975) meliputi pola lurus, lengkung, putaran dan buntu. Sementara fasilitas penunjang dalam lingkup perumahan dan permukiman dibangun berdasar aspek ekonomi dan sosial budaya. Fasilitas berdasar aspek ekonomi yaitu fasilitas berupa bangunan perniagaan atau perbelanjaan yang tidak mencemari lingkungan. Sedangkan fasilitas berdasar aspek sosial budaya, antara lain berupa bangunan pelayanan umum dan pemerintahan, pendidikan dan kesehatan, peribadatan, rekreasi dan olah raga, pemakaman, dan pertamanan. (Undang Undang No. 4 Tahun 1992). Bagaimana hubungan yang terjadi antara layout perumahan dan faktor kriminalitas di Perumnas Air Putih Samarinda menjadi rumusan permasalahan dalam penelitian ini. Faktor apa saja yang paling berhubungan, agak berhubungan dan tidak berhubungan sama sekali, menjadi hasil dalam penelitian ini.

\section{METODE PENELITIAN}

Penelitian ini adalah penelitian deduktif kualitatif dengan bentuk studi kasus di Perumnas Air Putih. Data-data selain dalam bentuk kualitatif, juga berbentuk kuantitatif, tetapi dalam proses analisis, data kuantitatif akan diterjemahkan menjadi data kualitatif.

Penelitian ini bertitik tolak dari teori dan konsep yang dihasilkan dari teori Housing Layout Untermann dan Small (1983). Parameter yang diturunkan dari konsep Housing Layout kemudian dihubungkan dengan kondisi layout Perumnas dan dianalisis dengan data empiris (data kriminalitas meliputi waktu, bentuk, lokasi, frekuensi dan obyek pencurian). Indikator penelitian dilakukan dengan merujuk kepada teori Defensible Space. Teknik analisis menggunakan teknik wawancara, observasi, $j$-graphs dan axial line. Teknik j-graphs dan axial line dikembangkan oleh Bill Hillier dan Hansons dalam Social Logic of Space (1984). Dua teknik terakhir dapat diterapkan pada denah bangunan, siteplan kawasan dan kota.

Tabel 1 membahas mengenai parameter, variabel, indikator dan teknik yang digunakan dalam penelitian ini.

Berdasar layout-nya, Perumnas Air Putih memiliki akses keluar masuk perumnas dan zona $1-4$ yang cukup banyak dan memiliki bentuk akses yang berbeda-beda. Pola sirkulasi dan pola hunian cukup beragam, terdapat sirkulasi yang banyak atau sedikit terhubung dengan sirkulasi lain dan ada pola hunian dengan bentuk linier yang pendek dan panjang. Fasilitas pun berbeda-beda jenis dan sifatnya antara satu dengan lainnya. Layout Perumnas Air Putih dapat terlihat pada Gambar 1. 
Tabel 1. Parameter, variabel, indikator dan teknik

\begin{tabular}{|c|c|c|c|}
\hline No & \multicolumn{3}{|c|}{ Parameter } \\
\hline \multirow[t]{6}{*}{1} & \multicolumn{3}{|c|}{$\begin{array}{l}\text { Teori housing layout (pada public housing) } \\
\text { Housing Layout adalah tata letak fisik elemen-elemen } \\
\text { dalam perumahan. Elemen yang berhubungan dengan } \\
\text { housing layout dalam penelitian ini adalah akses, pola } \\
\text { hunian, pola sirkulasi. dan fasilitas. }\end{array}$} \\
\hline & Variabel & Indikator & Teknik \\
\hline & Akses & $\begin{array}{l}\text { - Kedalaman ruang } \\
\text { - Bentuk akses } \\
\text { - Pembatasan akses }\end{array}$ & $\begin{array}{l}\text { Observasi } \\
\text { Wawancara } \\
\text { J-graphs } \\
\text { Axial line }\end{array}$ \\
\hline & Pola sirkulasi & $\begin{aligned} \text { - } & \text { Konektivitas } \\
- & \text { Kepadatan lalu } \\
& \text { lintas dan level } \\
& \text { jalan }\end{aligned}$ & $\begin{array}{l}\text { Observasi } \\
\text { Wawancara }\end{array}$ \\
\hline & Pola hunian & 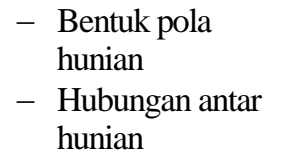 & Observasi \\
\hline & Fasilitas: & $\begin{array}{l}\text { - Jenis } \\
\text { - Sifat } \\
\text { - } \text { Mixed use dengan } \\
\quad \text { hunian }\end{array}$ & $\begin{array}{l}\text { Observasi } \\
\text { Wawancara }\end{array}$ \\
\hline 2 & $\begin{array}{l}\text { Kriminalitas } \\
\text { Batasan krimir } \\
\text { jenis pencuria } \\
\text { seluruhnya at: } \\
\text { maksud untul } \\
\text { (http://pakarhu } \\
\text { 30 Juni 2011) }\end{array}$ & $\begin{array}{l}\text { halitas pada tesis ini ad } \\
\text { n (yaitu mengambil su } \\
\text { qu sebagian milik ora } \\
\text { k dimiliki secara me } \\
\text { kum.site90.net/ pencuri }\end{array}$ & $\begin{array}{l}\text { alah kriminalitas } \\
\text { latu benda yang } \\
\text { ng lain, dengan } \\
\text { lawan hukum- } \\
\text { lan. php, diakses }\end{array}$ \\
\hline & Variabel & Indikator & Teknilk \\
\hline & $\begin{array}{l}\text { Jenis kriminal- } \\
\text { itas yaitu } \\
\text { pencurian }\end{array}$ & $\begin{array}{l}\text { - Bentuk } \\
\text { - Lokasi } \\
\text { - Waktu } \\
\text { - Frekuensi } \\
\text { - Obyek curian }\end{array}$ & $\begin{array}{l}\text { Observasi } \\
\text { Foto/sketsa } \\
\text { Wawancara }\end{array}$ \\
\hline
\end{tabular}

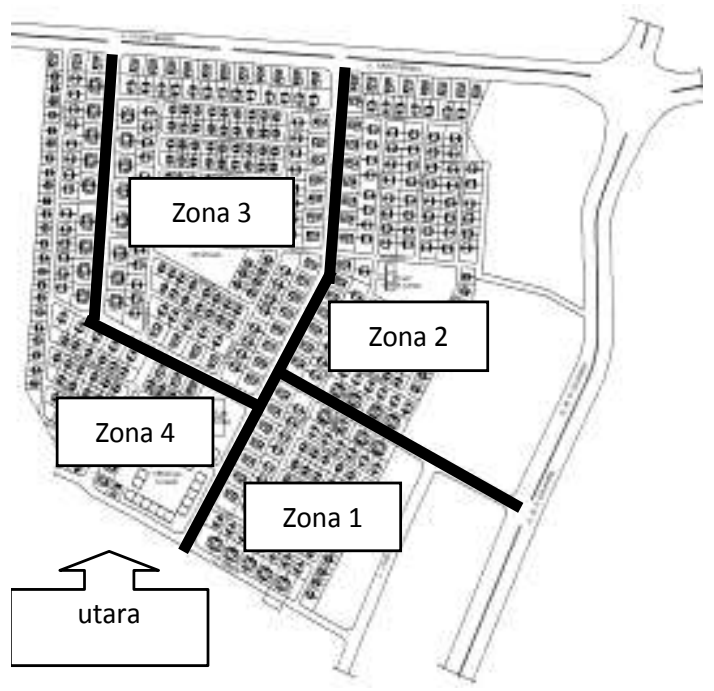

Gambar 1. Siteplan Perumnas Air Putih

Batas-batas dari masing-masing zona, terlihat pada Tabel 2.
Tabel 2. Batas-batas zona

\begin{tabular}{cll}
\hline Zona & \multicolumn{2}{c}{ Batas } \\
\hline `1 & Utara & Selatan \\
& Jl. Juanda 8 & Jl. Jambu 6 \\
& Barat & Timur \\
& Jl. Jambu & Perumahan tetangga \\
2 & Utara & Selatan \\
& Jl. Kadrie Oening & Jl. Juanda 8 \\
& Barat & Timur \\
& Jl. Rotan Semambu & Pertokoan \\
3 & Utara & Selatan \\
& Jl. Kadrie Oening & Jl. Rotan Segah \\
& Barat & Timur \\
& Jl. Rotan Pulut & Jl. Rotan Semambu \\
4 & Utara & Selatan \\
& Jl. Kadrie Oening & Jl. Jambu 6 \\
& Barat & Timur \\
& Permukiman Tetangga & Jl. Rotan Pulut-Jl. Rotan \\
& & Segah-Jl. Jambu \\
\hline
\end{tabular}

\section{HASIL DAN PEMBAHASAN}

Jenis kriminalitas di Perumnas Air Putih dalam rentang lima tahun terakhir didominasi oleh pencurian, yaitu pencurian biasa (cubis) dan pencurian dengan pemberatan (curat). Sebaran kasus pencurian di Perumnas Air Putih memunculkan level area yang paling rawan, sedang dan aman. Area paling rawan tercipta dari sebaran rumah korban pencurian dengan jumlah yang banyak dan saling berdekatan. Area kerawanan sedang adalah area rumah korban pencurian yang jumlahnya tidak terlalu banyak, sedangkan area aman adalah area yang di dalamnya cenderung tak ada rumah-rumah yang menjadi korban pencurian.

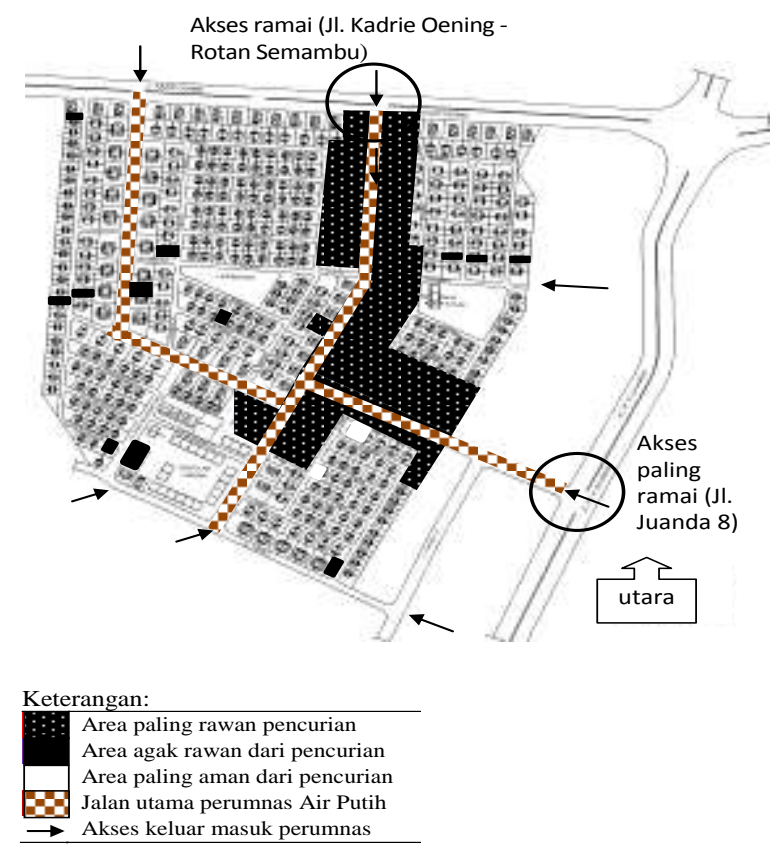

Gambar 2. Sebaran kasus pencurian (Data Polsekta Samarinda Ulu, 2005-2010) 
Keempat variabel komponen dari housing layout yaitu akses, pola sirkulasi, pola hunian dan fasilitas kemudian dihubungkan dengan faktor kriminalitas (pencurian) di Perumnas Air Putih.

\section{Akses}

Akses adalah entrance menuju ke suatu tempat atau tujuan. Akses masuk ke Perumnas Air Puth cukup banyak yaitu tujuh akses yang tersebar mengelilingi Perumnas Air Putih. Akses Perumnas Air Putih yang paling ramai adalah akses di Jl. Kadrie Oening - Jl. Rotan Semambu dan Jl. Juanda 8. Sementara akses lainnya lebih sepi dari lalu lalang kendaraan (Gambar 2).

Karakter akses pada perumnas Air Putih adalah akses yang terbuka tanpa pembatas menuju ke zonahalaman -bangunan dan didominasi bentuk akses tidak langsung. Dilihat dari area level pencurian, jumlah kasus pada area paling rawan berjumlah 26 kasus rumah kecurian (14 rumah memiliki akses langsung, 12 berada pada akses tidak langsung). Korban pencurian di area kriminalitas (pencurian) sedang, banyak terjadi pada rumah-rumah yang memiliki akses tidak langsung dan didominasi rumah di tepi gang.

Rumah-rumah yang diakses langsung dari tujuh akses menuju perumnas memiliki kesamaan yaitu berada pada ruang (berupa jalan) yang pasti terdapat korban pencurian. Semakin ke bagian dalam Perumnas, kasus pencurian semakin berkurang. Hal ini terlihat dari teknik justified graphs atau j-graphs yang digunakan.

Tidak ada pembatasan akses masuk ke Perumnas dan zona rumah-rumah. Pembatasan akses mulai diterapkan oleh warga pada akses menuju halaman dan bangunan rumah. Pembatasan akses dilakukan melalui pagar rumah dan pintu rumah-rumah yang cenderung tertutup dan terkunci.

Terdapat pula rumah-rumah yang tidak berpagar dan pemilik rumah sering membiarkan pintu rumah dalam keadaan terbuka, terutama pada area aman di bagian dalam zona 1-4, tetapi jumlahnya tidak terlalu banyak. Hunian di area ini kebanyakan berada pada kedalaman ruang yang dalam, dan tidak terhubung langsung dengan akses Perumnas Air Putih yang ada.

Keterhubungan rumah dengan akses Perumnas Air Putih dan kedalaman ruang (rumah) berhubungan erat dengan faktor kriminalitas (pencurian). Artinya bahwa posisi rumah yang dilewati langsung oleh salah satu dari tujuh akses Perumnas Air Putih maka akan semakin rawan pencurian. Semakin dalam posisi rumah dari akses utama perumnas, maka rumah cenderung semakin aman dari pencurian.
Sedangkan bentuk pencapaian (langsung/tidak langsung) adalah faktor yang sedikit berhubungan dengan kriminalitas (pencurian). Artinya rumah yang dicapai secara langsung/tidak langsung dari jalan utama, tidak terlalu berkaitan dengan kerawanan pencurian.

Hal yang tidak berhubungan mengenai variabel akses adalah bentuk akses yang terbuka ke Perumnas Air Putih dan zona 1-4. Tidak ditemukan kaitan antara keseragaman bentuk akses ini dengan pola sebaran kriminalitas.

Pengecualian untuk kasus curanmor, semua terjadi pada rumah dengan akses terbuka ke halaman rumah. Lebih mudah bagi pencuri untuk mencuri motor yang berada dalam ruang tanpa halangan berupa pagar.

\section{Pola Sirkulasi}

Pola jalan di Perumnas Air Putih adalah modifikasi dari grid, memiliki jalan-jalan tembus seperti pola grid tetapi dengan bentuk jalan kombinasi linier yang saling terkoneksi. Terdapat beberapa perempatan dan pertigaan jalan yang memudahkan pengguna jalan untuk mencari jalan alternatif menuju tempat tertentu di Perumnas Air Putih. Hanya sedikit jalan buntu (cul de sac) di Perumnas Air Putih. Kepadatan jalan pun beragam, ada yang padat atau sepi pada jam-jam tertentu.

Secara struktur, jalan dibagi menjadi 3 level yaitu level utama (Jl. Juanda 8, Jl. Rotan Semambu, Jl. Jambu (Rotan Semambu Selatan), Jl. Rotan Segah dan Jl. Rotan Pulut), level sedang (Jl. Salak/ Jl. Rotan Sempurut dan Jl. Jambu 6) dan level kecil (gang di bagian dalam zona).

Struktur jalan ini berdasar kemudahan pencapaian (strategis), kepadatan pengguna jalan dan lebar jalan (berkaitan dengan jenis moda yang dapat melalui jalan tertentu). Jalan level utama dapat dilalui moda roda empat yang dapat saling berpapasan dalam satu waktu. Jalan level sedang hanya bisa dilalui oleh dua mobil, tetapi tak bisa bergerak berpapasan dalam satu waktu, dan jalan level kecil hanya dilalui oleh satu kendaraan roda empat saja atau hanya kendaran roda dua saja.

Akses dan pola sirkulasi saling berhubungan antara satu dengan lainnya. Analisis mengenai pola sirkulasi dilakukan dengan melihat index axial connectivity. Axial connectivity berkaitan dengan jalan-jalan yang saling terhubung. Terlihat dalam peta axial line pada gambar 4, hirarki jalan-jalan yang memiliki nilai indeks axial connectivity tinggi, sedang hingga rendah. Semakin tinggi nilai indeks axial connectivity pada suatu jalan maka semakin banyak jalan lain yang terhubung. 


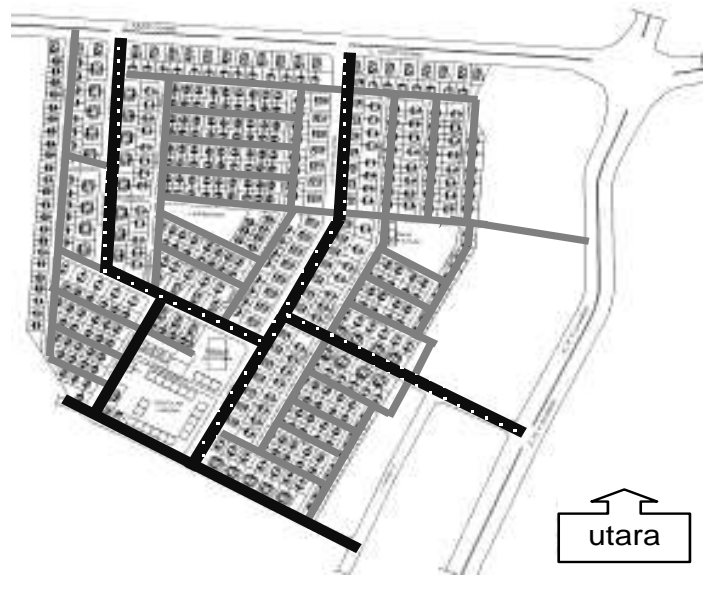

Keterangan:

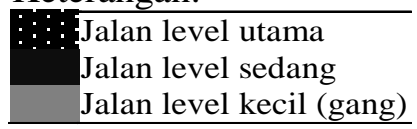

Gambar 3. Level jalan di Perumnas

Kasus pencurian mayoritas terjadi pada rumah yang berada pada jalan dengan indeks axial connectivity tinggi, sementara pada rumah di tepi jalan dengan indeks axial connectivity sedang dan rendah, kasus pencurian semakin rendah. Bahkan di jalan buntu (cul de sac), tidak ada kasus pencurian sama sekali. Hal ini karena tersedianya banyak jalan alternatif untuk masuk dan melarikan diri bagi pencuri pada jalan dengan indeks axial connectivity tinggi. Hal ini berbeda jika dibandingkan dengan penelitian Baran, Smith dan Toker (2006) dalam jurnal Conflict between Space and Crime: Exploring the Relationship betwee Spatial Configuration and Crime Location, di mana pada ruang dengan indeks axial connectivity tinggi, tingkat kriminalitas justru rendah.

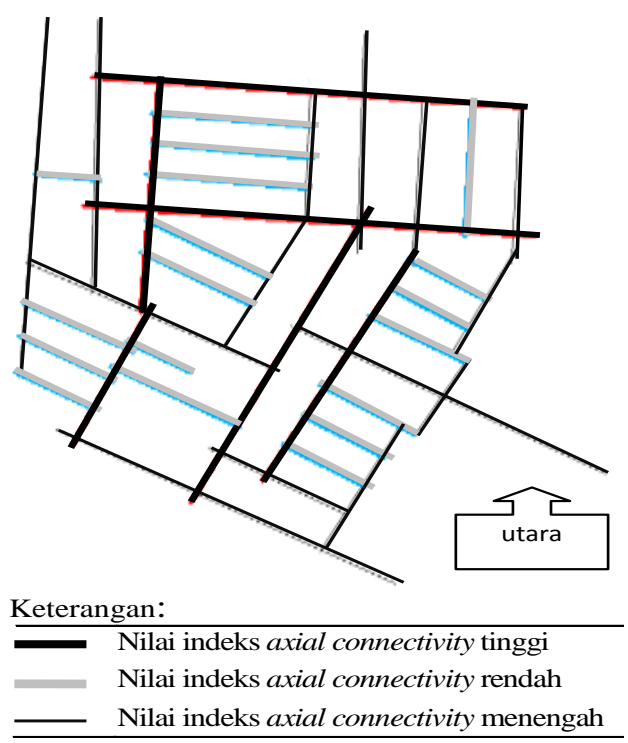

Gambar 4. Peta Axial Line
Lebar jalan di perumnas terbagi atas jalan yang lebar, sedang dan sempit (gang), begitupun kepadatan lalu lintas, terdapat jalur yang padat lalu lintas, agak padat dan sepi. Sebaran kriminalitas tidak terkumpul pada jalan dengan lebar dan kepadatan tertentu, tetapi hampir tersebar merata. Dapat dikatakan bahwa faktor lebar jalan dan kepadatan lalu lintas, sedikit berhubungan dengan kriminalitas (pencurian).

Di titik-titik tepat di persimpangan jalan, baik itu perempatan atau pertigaan, kasus pencurian sangat sedikit. Perempatan atau pertigaan tidak terhubung dengan faktor kriminalitas di Perumnas Air Putih.

\section{Pola hunian}

Pada tahun 80-an, tipe rumah di sisi luar zona adalah tipe besar yaitu tipe 70 dan 54, sedangkan di bagian dalam zona terdiri dari tipe 25 dan 15 . Kini semua rumah-rumah memiliki lantai lebih luas, KDB (Koefisien Dasar Bangunan) hampir 100\% dan bertingkat. Desain rumah pun telah berubah sama sekali, tidak ada lagi rumah asli yang ditemukan di Perumnas Air Putih. Sekarang, rumah-rumah di tepi jalan utama cenderung terlihat megah dibandingkan dengan rumah di bagian dalam zona, hal ini terkait juga dengan tingkat penghasilan yang berbeda. Rumah-rumah terluar umumnya dimiliki oleh warga dengan penghasilan lebih tinggi daripada warga di dalam zona.

Pola hunian di Perumnas Air Putih adalah pola linier. Deret terpendek dihuni oleh 2 rumah, sedang deret terpanjang dihuni hampir 50 rumah. Deret hunian rata-rata terdiri dari 20 an rumah.

Hampir semua deret rumah saling menghadap dan membelakangi deret hunian rumah yang lain. Pada deret rumah di sisi terluar zona, terdapat rumahrumah yang menghadap ke arah permukiman tetangga, ke jalan raya dan ke fasilitas umum di Perumnas Air Putih.

Hubungan antara rumah-rumah di deret linier yang sama, menciptakan posisi rumah di tusuk sate, hoek, area tepi deret dan area tengah deret.

Kasus pencurian di area paling rawan umumnya lebih banyak terjadi pada rumah yang berada di area tepi dibandingkan dengan area tengah deret rumah, tetapi dengan perbedaan yang tidak terlalu signifan. Dapat dikatakan bahwa posisi rumah pada deret linier, sedikit berhubungan dengan faktor kriminalitas.

Jarak antar deret rumah tidak terlalu jauh sehingga memungkinkan antar tetangga bisa saling melihat kondisi rumah tetangga di deret yang lain, tetapi dengan jangkauan pandang hanya sekitar 3-4 rumah (Gambar 5). Justru pada deret linier yang sama, antar tetangga tidak semua bisa saling mengawasi karena terbatasnya jarak visual. 


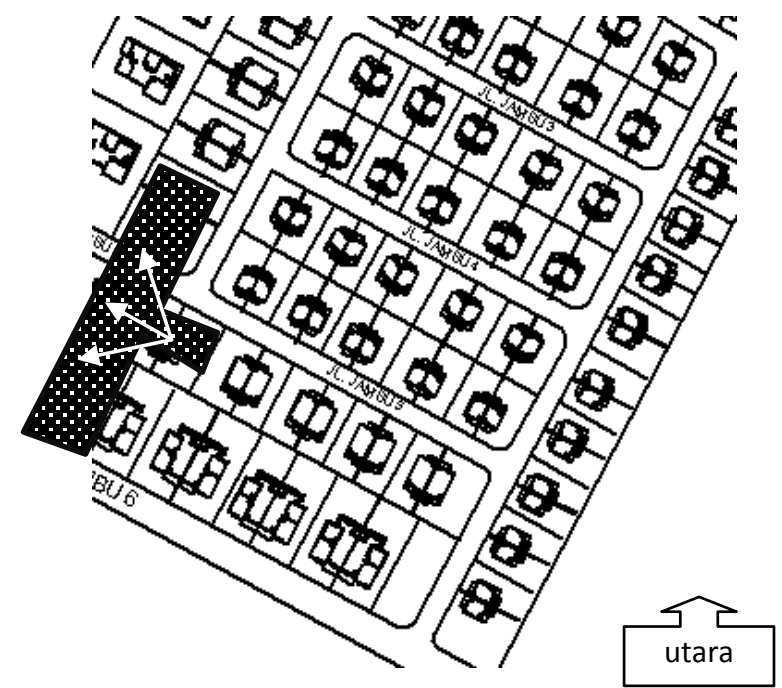

Gambar 5. Terbatasnya pandangan visual pada pola hunian linier

Kendala pengawasan ke lingkungan, selain karena desain pagar yang masif dan tinggi, juga disebabkan pencahayaan yang minim di malam hari, yang hanya mengandalkan lampu teras dari rumahrumah warga. Kejadian kriminalitas paling banyak terjadi di malam hingga dini hari, di saat warga umumnya beristirahat.

Rumah dengan posisi hoek atau tusuk sate hampir-hampir tak ada yang menjadi korban pencurian sehingga hal ini tidak berhubungan dengan kejadian kriminalitas (pencurian). Rumah yang saling berhadapan dan saling membelakangi juga tidak berhubungan dengan kriminalitas (pencurian), karena bentuk tersebut adalah pola hunian Perumnas Air Putih secara umum.

\section{Fasilitas}

Fasilitas di Perumnas Air Putih sebagian dibangun oleh pengelola Perum Perumnas Air Putih, seperti fasilitas lapangan, masjid dan lain-lain, tetapi ada pula yang dibangun warga misalnya posyandu \& poskamling dan terdapat pula fasilitas yang dibangun oleh individu seperti toko kelontong. Sifatnya pun dibedakan menjadi fasilitas komersil dan non komersil. Fasilitas yang dibangun pengelola dan sesama warga, sifatnya cenderung non komersil. Sementara fasilitas yang dibangun individu adalah bersifat komersil.

Letak fasilitas berdampingan dengan rumahrumah warga, ini berarti terdapat fungsi-fungsi ruang yang berbeda dalam satu area atau zona (mixed use).

Zona fasilitas A terdiri dari masjid, SD Swasta, SD Negeri, puskesmas dan sanggar belajar. Suasana di pagi hingga siang hari cukup ramai. Menjelang sore hingga dini hari, cenderung sepi, hanya masjid yang berfungsi 24 jam sehari. Zona fasilitas B adalah lapangan terbuka yang cenderung hanya ramai di sore hari ketika anak-anak bermain. Zona fasilitas $\mathrm{C}$ terdiri dari gedung bulutangkis, posyandu, aula, lapangan terbuka kecil, dan TK (Taman Kanak-kanak). Suasana cukup ramai di pagi hingga sore hari. Malam hari terkadang cukup ramai oleh orang yang bermain bulu tangkis di gedung bulutangkis.

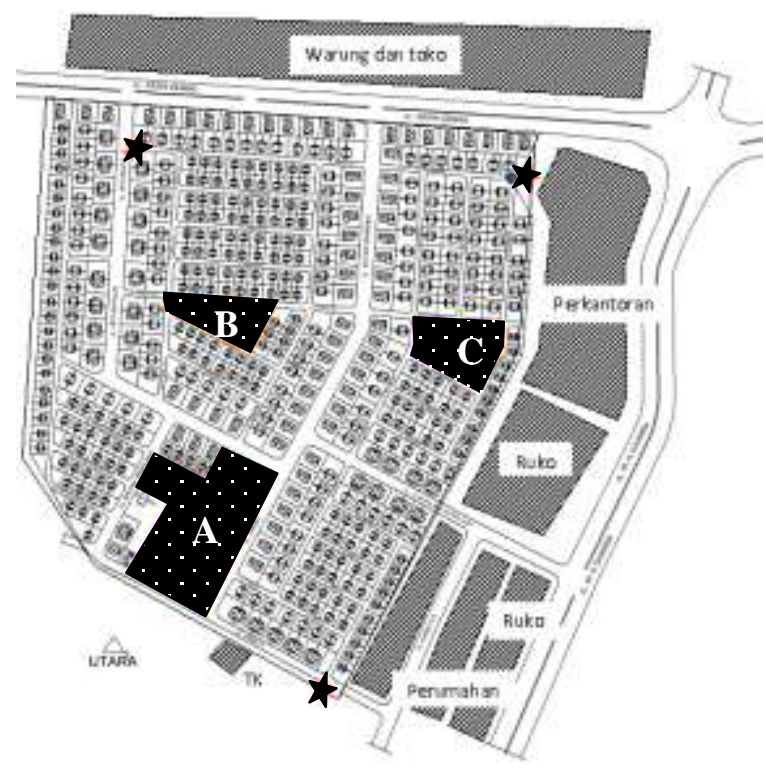

Keterangan:
A
B
C.
A
Zona fasilitas warga Perumnas Air Puth dan masyarakat kota Samarinda, zona 4, cenderung rawan kriminalitas
Zona fasilitas hanya bagi warga Perumnas Air Putih, zona 3, cenderung aman.
Zona fasilitas hanya bagi warga Perumnas Air Putih, zona 2, cenderung aman.
Fasilitas keamanan Perumnas Air Putih yaitu pos ronda

\section{Gambar 6. Perletakan fasilitas}

Walaupun jumlah rumah yang mengelilingi zona fasilitas A hanya sedikit, tetapi jumlah korban pencurian justru yang terbanyak. Zona fasilitas A berada di tepi Jl. Jambu (Jl. Rotan Semambu selatan). Zona fasilitas A ini cenderung sepi dan gelap di malam hari. Hanya masjid yang tampak cukup terang, tetapi aktivitas ibadah tak terlalu padat, kecuali di bulan Ramadhan. Waktu sholat lain seperti sholat Dzuhur, Maghrib dan Jum'at adalah waktu yang cukup ramai dengan kehadiran jamaah yang beribadah sholat.

Masjid berada di tepi jalan Jambu/Rotan Semambu Selatan. Akses menuju masjid dapat dilalui dari banyak arah dan akses tidak dibatasi atau dikontrol oleh warga Perumnas Air Putih. Pengunjung masjid pun tidak dibatasi, sehingga siapa pun dapat memasuki masjid, termasuk pencuri yang 
mengincar barang-barang di rumah-rumah warga di sekitar masjid. Bahkan rumah penjaga masjid pun pernah menjadi korban pencurian di saat sholat Subuh sedang berlangsung.

Bagian fasilitas A di bagian selatan bersuasana sepi dan gelap, dan beberapa waktu sempat menjadi tempat berkumpul anak muda yang melakukan aktivitas negatif seperti mabuk-mabukan. Bagian ini rawan dijadikan akses masuk bagi pencuri untuk mengincar korban, selain karena gelap, juga luput dari pengawasan warga. Kasus zona fasilitas A menggambarkan perletakan rumah dan fasilitas dalam satu area/blok dengan jumlah rumah yang sedikit, berpengaruh terhadap kerawanan kriminalitas (pencurian), di Perumnas Air Putih.

Zona fasilitas $\mathrm{B}$ dan $\mathrm{C}$ berada di dalam zona 2 dan 3. Justru di sekitar zona fasilitas ini, kasus pencurian hanya sedikit. Pengguna fasilitas di zona B dan $\mathrm{C}$ adalah warga Perumnas Air Putih sendiri. Pengawasan ke zona fasilitas $\mathrm{B}$ dan $\mathrm{C}$ juga relatif mudah karena dikelilingi banyak rumah warga yang menghadap ke zona fasilitas.

Mixed use antara fasilitas umum (fasum) dan rumah tinggal, cenderung aman jika jumlah rumah tinggal lebih banyak dan fasum digunakan oleh warga Perumnas Air Putih. Mixed use antara fasilitas umum dan rumah tinggal cenderung tidak aman jika jumlah rumah tinggal lebih sedikit dan fasum digunakan oleh tak hanya warga Perumnas Air Putih, tetapi juga warga kota Samarinda. Hasil ini serupaa dengan penelitian Professor Bill Hillier dan Ozlem Sahbaz dalam jurnal berjudul An Evidence based Approach to Crime and Urban Design or We can have Vitality, Sustainability and Security All at once (2005), bahwa mixed use relatif aman bila jumlah rumah tinggal banyak dan rawan bila jumlah rumah tinggal sedikit.

\section{KESIMPULAN}

Hubungan yang dihasilkan dari layout perumahan dan kriminalitas adalah hubungan yang sangat erat, sedikit dan tidak ada hubungan sama sekali. Faktor yang paling berhubungan antara layout perumahan dan kriminalitas adalah koneksi langsung antara rumah dengan akses perumahan (koneksi langsung meningkatkan kriminalitas), kedalaman ruang (semakin dalam posisi rumah maka akan semakin aman), indeks konektivitas aksial (semakin tinggi nilai indeks maka semakin rawan kriminalitas) dan mixed use (semakin banyak rumah di dekat area fasilitas akan menciptakan area yang lebih aman dibandingkan dengan sedikit rumah di dekat area fasilitas).

Faktor yang sedikit berhubungan adalah bentuk akses (langsung/tidak langsung) ke rumah tinggal, kepadatan lalu lintas, lebar jalan dan posisi rumah pada deret linear. Faktor yang tidak berhubungan adalah bentuk akses (langsung/tidak langsung) ke Perumnas dan zona 1-4, kedekatan rumah dengan persimpangan jalan, bentuk deret rumah, dan arah fasad rumah.

Saran di bidang penelitian, dapat dilakukan penelitian lebih lanjut dalam tema arsitektur dan perilaku, misalnya perilaku defensif penghuni perumnas tehadap kerawanan kriminalitas. Sedangkan saran di bidang perencanaan perumahan adalah perencanaan akses perumahan yang terkontrol, sirkulasi yang terpisah dengan jalur umum, pola hunian yang memungkinkan pengawasan antar tetangga dengan baik, dan perletakan fasilitas dalam blok hunian, jumlah hunian harus lebih banyak dibandingkan dengan jumlah/luas fasilitas.

\section{DAFTAR PUSTAKA}

Baran, P.K., W.R. Smith and U. Toker (2006). Conflict between Space and Crime: Exploring the Relationship between Spatial Configuration and Crime Location. Paper presented at EDRA37. Atlanta.

Chiara, J.D., and Lee E. K. (2008). Standar Perencanaan Tapak, Penerbit Erlangga, Bandung.

Hillier, B. and Hansons (1984). The Sosial Logic of Space, Cambridge University Press.

Hillier, B., and Ozlem S. (2005). An Evidence based Approach to Crime and Urban Design or We can have Vitality, Sustainability and Security All at once. www.spacesuntax.org.

Kapolsekta Samarinda Ulu. Data Kriminalitas Kecamatan Samarinda Ulu 2005-2010.

Newman, O. (1972). Defensible Space, Crime Prevention Through Urban Design, Macmillan, New York.

Untermann, R.K., and R. Small (1983). Site Planning for Cluster Housing (Perencanaan Tapak untuk Perumahan). Penerjemah: Vincent M. Intermedia. Jakarta.

Undang Undang No. 4 Tahun 1992, Tentang Perumahan Rakyat. 